\section{Teaching the Tough Topics: Fostering Ideological Awareness through the Inclusion of Societally Impactful Topics in Introductory Biology}

\author{
Abby E. Beatty, ${ }^{* *}$ Emily P. Driessen, ${ }^{\dagger}$ Taylor Gusler, ${ }^{\dagger}$ Sharday Ewell, ${ }^{\dagger}$ Amy Grilliot, ${ }^{\dagger}$ \\ and Cissy J. Ballen' \\ 'Department of Biological Sciences, Auburn University, Auburn, AL 36849; 'Biology and \\ Environmental Sciences, Auburn University at Montgomery, Montgomery, AL 36117
}

\begin{abstract}
While science has profound social impacts, we often teach biology as removed from societally debated issues. Here, we address this gap in biology education through the implementation of novel materials that promote ideological awareness (IA). Using mixed-method analyses, we explore students' perceptions of the relationship between science and society, as well as their attitudes toward and knowledge of IA in biology. We found students that received the IA curriculum reported relationships between science and society that aligned with the IA activities, such as providing solutions to societal problems and combating misinformation. Additionally, we discovered a preference for IA materials over a traditional curriculum, with persons excluded because of their ethnicity and race (PEERs) reporting greater approval than non-PEERs. Although we found that the IA curriculum did not result in significant gains in science identity, engagement in biology, or science community values, we did find that students gained awareness of IA topics through a task in which they named as many scientists as possible. Specifically, IA students displayed a $300 \%$ increase in the frequency of named scientists from minoritized backgrounds compared with the traditionally taught students. We encourage instructors to incorporate IA materials into their curricula as we move toward more diverse, equitable, and inclusive teaching practices.
\end{abstract}

\section{INTRODUCTION}

Science has profound impacts on society, yet instructors often teach science as though it is divorced from societal issues. Traditional scientific training exclusively prepares students for scientific practice without helping students navigate social concepts. This is particularly true for potentially controversial issues at the intersection of biology and politics, religion, race, or LGBTQIA+ identity. Instructors may be hesitant to discuss these issues, preferring instead to stick to the traditional "value-free" biology curriculum, which suggests that social and ethical values should have no influence on the conduct of science and that scientists should have little concern for such values (Cross and Price, 1996; Douglas, 2009). However, choosing not to address these topics in the classroom perpetuates the falsity that biology as a field is removed from these social issues.

Despite the prevalence of the value-free biology curriculum, critical pedagogy theory supports the idea that science and society are not separate entities. Instead, critical pedagogy views education as a process of problem-posing and self-discovery, developing one's power and capacities with an open mind and in cooperation with others, rather than only memorization and recitation (Freire and Macedo, 2018). Through this process, students draw connections with the world around them and understand the impacts of their field on the functionality of society. Making the connections
Clark Coffman, Monitoring Editor Submitted Apr 23, 2021; Revised Sep 15, 2021 ; Accepted Sep 17, 2021

CBE Life Sci Educ December 1, 2021 20:ar67 DOI:10.1187/cbe.21-04-0100

Conflict of interest: Abby E. Beatty developed the curriculum presented in this article. No promotion of a particular product to the exclusion of other similar products should be construed

*Address correspondence to: Abby E. Beatty (aeb0084@auburn.edu)

(C) 2021 A. E. Beatty et al. CBE-Life Sciences Education ๑ 2021 The American Society for Cell Biology. This article is distributed by The American Society for Cell Biology under license from the author(s). It is available to the public under an Attribution-Noncommercial-Share Alike 3.0 Unported Creative Commons License (http://creativecommons.org/licenses/ by-nc-sa/3.0).

"ASCB®" and "The American Society for Cell Biology $\AA^{\circ}$ are registered trademarks of The American Society for Cell Biology. 
between science and society is also one of six core competencies in undergraduate biology promoted by the American Association for the Advancement of Science (AAAS, 2011) in a formative document, Vision and Change in Undergraduate Biology Education: A Call to Action.

Instructors are the "link" between the world of science and society. They have an important role in guiding their students to function as critical citizens (Lazarowitz and Bloch, 2005). Linking societal issues to biological concepts allows students to formulate their own positions while also advancing their critical-thinking, decision-making, argumentative, reflective judgment, and scientific literacy skills (Aikenhead, 1985, 2002; Solomon, 1992; Zeidler et al., 1992, 2005; Zeidler, 1997; Sadler and Zeidler, 2004; Sadler et al., 2006; Zohar and Nemet, 2002; Driver et al., 2000; Dawson and Venville, 2010; Eastwood et al., 2012). If a goal in science education is to develop a scientifically literate population capable of making informed decisions in a democracy, then issues that sit at the intersection of biology and society should be a defining component of any biology curriculum.

One way to meet this goal is through teaching ideological awareness (IA), an understanding of biases, stereotypes, and assumptions that shape contemporary and historical science. Contemporary philosophers of science have described the importance of acknowledging the role of values in science and incorporating them thoughtfully and with scrutiny, rather than not at all, highlighting the critical role of IA in disciplinary study (Elliott, 2017; Potochnik, 2020). An IA curriculum opposes a value-free ideal for science, accepts the pervasive role that values have in all aspects of science and enables students to challenge prevailing worldviews and the status quo. IA activities occur in the classroom when the topic is thematized-for example, an activity in which students discuss the consequences when a majority of studies in medical sciences disproportionately focus on white cis-men (Perez, 2019). As a result, we know far less about how various ailments manifest in cis-gender women, transgender people, nonbinary people, and people of color. This has consequences for the next generation of doctors and policy makers, who must be able to characterize best practices for a global population, evaluate medical responses, and prioritize the recipients of available treatments.

Teaching IA may include discussions of biases and stereotypes that shape our perception of what a scientist looks like. For many students, perceptions of scientists are shaped by those who are highlighted in textbooks. One demographic analysis that extracted over 1000 human names from common biology textbooks and assessed the binary gender and race of featured scientists showed that the most commonly scientists were white men (Wood et al., 2020). Assuming the current rate of change continues, their projections suggested that it could take multiple centuries before textbooks reach inclusive representation (Wood et al., 2020). By exclusively highlighting stereotypical scientists, we not only communicate to students who scientists have been, but who they can be. These perceptions begin forming early in development; in one classic longitudinal study (Chambers, 1983), researchers asked children to participate in a "Draw a Scientist Test." Most children drew what they believed a stereotypical scientist looked like: an intellectual, white cis-gender man draped in a white lab coat (Chambers, 1983).
However, after being provided the opportunity to engage with scientists of different identities, perceptions of what a scientist looked like changed to include diverse identities (Phillips and Hausbeck, 2000). Following years of exposure to scientific media and course work, drawings produced by undergraduate students still exhibited stereotypic characteristics similar to those drawn by children in grade school (Thomas et al., 2006). But research shows highlighting counter-stereotypical examples of scientists can increase undergraduate students' interest in science, performance outcomes, and ability to relate to scientists (Schinske et al., 2016).

In light of these social discrepancies and in the wake of recent social reckoning and unrest in the United States, calls for teaching societally relevant topics in science, technology, engineering, and mathematics (STEM) classes have reached a crescendo (Dzirasa, 2020; Gewin, 2020; Schell et al., 2020; Simpson et al., 2021). Sustained action that diversifies and integrates IA into curricula will increase students' ability to apply scientific and moral reasoning to real-world situations. With this in mind, we developed an integrated curriculum that included three modules that encouraged respectful and productive conversation among students and addressed important areas that are generally not emphasized in introductory biology.

We then used this curriculum to explore the following research questions: 1) What are students' perceptions of the relationship between science and society? 2) How are science identity, engagement in biology, and science community values impacted by the inclusion of IA materials? 3) Do students prefer IA materials in the context of an introductory biology course? 4) How does student knowledge of societally impactful topics change after exposure to IA materials?

\section{METHODS}

To answer our research questions, the lead author (A.E.B.) developed a three-lesson IA curriculum and implemented it in one section of an introductory biology course in Fall 2020, collecting student data via pre- and post-course surveys. For comparison, we collected the same student survey data from another section of the course taught by a different instructor at the same institution. Both instructors followed the same main curricular content, containing congruent learning objectives. The students were assessed similarly and taught the materials in similar formats. Thus, the primary difference between the two sections was the implementation of the three-lesson IA curriculum and the instructor.

\section{Curricular Development}

The curriculum consisted of three modules: 1) "The Ugly Truth: Unethical Experimentation and Human Rights Evolution," 2) "Representation in STEM," and 3) "Intersection of Science and Identity." The modules will hereafter be referred to by abbreviated names: "The Ugly Truth", "Representation in STEM", and "Science and Identity". The modules take a "past, present, future" approach to discussing the progression of biology, highlighting the current trajectory of the field. For example, students were informed that "the father of gynecology" performed experiments on enslaved Black women without anesthesia because he believed they could not feel pain, and this was a legal act at that time. The instructor then acknowledged that practices such as these are presently illegal, discussing the 
TABLE 1. IA Curriculum details

\begin{tabular}{|c|c|c|c|}
\hline Module $^{a}$ & Learning objective & Lesson topics & Student activity \\
\hline $\begin{array}{l}\text { "The Ugly Truth: Unethical } \\
\text { Experimentation and } \\
\text { its Relation to Human } \\
\text { Rights Evolution"1,3,6,7 }\end{array}$ & $\begin{array}{l}\text { Explore the exploitative nature of } \\
\text { science history through the } \\
\text { lens of human rights } \\
\text { evolution, bringing student } \\
\text { attention to the impacts of } \\
\text { unethical scientific practices } \\
\text { on vulnerable populations. }\end{array}$ & $\begin{array}{l}\text { 1. Eugenics } \\
\text { 2. The exploitation of at-risk groups and } \\
\text { unethical human experimenta- } \\
\text { tion: e.g., tuskegee syphilis study, } \\
\text { malaria testing at Stateville Peniten- } \\
\text { tiary, Willowbrook State School } \\
\text { hepatitis study, J Marion Sims surgical } \\
\text { experimentation, Japan's Unit 731, } \\
\text { Germany twin experiments } \\
\text { 3. Environmental racism } \\
\text { 4. Disparities in healthcare access for } \\
\text { minoritized groups }\end{array}$ & $\begin{array}{l}\text { Student presentation: groups of } \\
\text { students (three to four) gave a } \\
\text { 10-minute presentation on one } \\
\text { of the examples listed under } \\
\text { lesson topics. Required } \\
\text { information included: summary } \\
\text { of event, ethical violations, } \\
\text { groups involved and reasons } \\
\text { for vulnerability, societal } \\
\text { responses, current ethical } \\
\text { advances preventing reoccur- } \\
\text { rence, biological concepts } \\
\text { influenced. }\end{array}$ \\
\hline $\begin{array}{l}\text { "Intersection of Science } \\
\text { and Identity",2,3,7 }\end{array}$ & $\begin{array}{l}\text { Address the ways in which } \\
\text { science has been used as } \\
\text { support for societal suppres- } \\
\text { sion of nonconforming identi- } \\
\text { ties and discuss the biological } \\
\text { nature of individualistic } \\
\text { identities. }\end{array}$ & $\begin{array}{l}\text { 1. Biological and social constructs: race } \\
\text { versus ancestry } \\
\text { 2. Biological and social constructs: sex } \\
\text { versus gender } \\
\text { 3. Biological support for gender identity } \\
\text { and sexuality } \\
\text { 4. Invalid and historical use of biol- } \\
\text { ogy in support of reprogramming and } \\
\text { sexual orientation change efforts } \\
\text { 5. Addressing the false stereotype } \\
\text { between gender identity and mental } \\
\text { illness } \\
\text { 6. The opportunities for coexistence of } \\
\text { evolution and religion through the } \\
\text { limitations of science }\end{array}$ & $\begin{array}{l}\text { Henrietta Lacks reflective writing: } \\
\text { students wrote a final reflection } \\
\text { (four to five pages) on 1) a } \\
\text { summary of the text and their } \\
\text { feelings on the personal story } \\
\text { of Henrietta Lacks and 2) the } \\
\text { evolution of tissue research and } \\
\text { legal ownership of body tissues. }\end{array}$ \\
\hline $\begin{array}{c}\text { "Representation in } \\
\text { STEM" } ", 3,4,5,6,7,8\end{array}$ & $\begin{array}{l}\text { Expose students to the invaluable } \\
\text { scientific contributions of } \\
\text { scientists from diverse } \\
\text { backgrounds, addressing the } \\
\text { biological and psychological } \\
\text { importance of representation } \\
\text { within the field. }\end{array}$ & $\begin{array}{l}\text { 1. Lack of representation in STEM: from } \\
\text { "Draw a Scientist Study" to represen- } \\
\text { tation in textbooks and faculty } \\
\text { members } \\
\text { 2. The unconscious of science } \\
\text { 3. Prominent scientists from minoritized } \\
\text { backgrounds: Charles Drew, Alice } \\
\text { Augusta Ball, George Washington } \\
\text { Carver, Gladys West; the wealth of } \\
\text { diverse scientists available: Proj- } \\
\text { ect BioDiversify, } 500 \text { Women } \\
\text { Scientists, } 500 \text { Queer Scientists }\end{array}$ & $\begin{array}{l}\text { Role model activity: each student } \\
\text { identified a real-life biologist } \\
\text { who they viewed as a role } \\
\text { model and with whom they } \\
\text { personally identify. They then } \\
\text { wrote a summary of the } \\
\text { scientist, their personal } \\
\text { connection, their science, and } \\
\text { how a combination of their } \\
\text { science and identity have } \\
\text { impacted the field. }\end{array}$ \\
\hline
\end{tabular}

a Introductory benchmark topics reinforced in module: ${ }^{1}$ Genetics, ${ }^{2}$ Evolution, ${ }^{3}$ Anatomy and Physiology, ${ }^{4}$ Bioinformatics, ${ }^{5}$ Ecology, ${ }^{6}$ Toxicology, ${ }^{7}$ Ethics, ${ }^{8}$ Scientific Engineering.

advancement of human medical rights. Additionally, New York removed the doctor's statue from Central Park and relocated it to his burial site, as people now recognize his wrongdoings. Finally, the instructor explained what a future with equal healthcare rights would look like, acknowledging current disparities among minoritized communities such as the Black and LGBTQ+ communities. For further detail on each module and how we integrated them into the biology curriculum, see Table 1. We discussed each IA module following traditional disciplinary materials, connecting the IA materials with core benchmarks of introductory biology. We explicitly made connections between the IA materials, the disciplinary concepts, and their societal importance, rather than assuming students would do so intuitively. The lead author (A.E.B.) delivered one module per class period for the last three class periods of the semester. In addition to these modules, she also replaced required read- ings from the traditional textbook with The Immortal Life of Henrietta Lacks. Chapters from this book were assigned over the course of the semester and were easily integrated into multiple benchmark topics for the introductory course in addition to the IA modules. Additionally, the traditional textbook was required for students for the sake of comparison. While students were not assigned mandatory readings from the traditional textbook, for each lecture, we provided students with the corresponding textbook chapters and encouraged them to consult the text for additional information.

\section{Student Population and Class Setting}

We collected data from two sections of a nonmajors Introductory Biology course taught at a public university in the southeast region of the United States. The Introductory Biology course is a three-credit class that includes two 75-minute class sessions 
each week. The instructors of both course sections taught lecture materials in an online format, in which materials (lectures, PowerPoints, etc.) and learning objectives were provided electronically through the class learning platform (i.e., BlackBoard). In the traditional section, students participated in active-learning activities individually online, while in the IA section students completed active learning activities individually in the classroom (in person, but socially distanced due to COVID-19 restrictions). The paper's lead author (A.E.B.) instructed the treatment section with the IA curriculum she created, and a coauthor (A.G.) taught the comparison section at the same university using the traditional curricular materials. To maintain consistency between the two sections and to avoid influencing student responses on the pre-course survey, instructors did not emphasize the presence or absence of IA topics in the semester's curriculum, beyond their inclusion in syllabus materials. The total enrollment for the course was 111 students across the two sections (55 in the IA section and 56 in the traditional section, with 51 and 38 students participating in either the pre-course survey, post-course survey, or both, respectively; Table 2).

\section{Data Collection}

We provided students with an electronic survey via Qualtrics at the end of the second week of the course and following the final class meeting of the semester. We offered a small amount of extra credit as an incentive to participate. As survey responses were anonymous, the entire class was offered bonus credit if $80 \%$ of the class submitted the survey by the deadline. Students provided a unique identifier consisting of the first three letters of their mother's name and first three numbers of their street address. Unique identifiers were used to pair pre- and postcourse survey data.

Briefly, the survey consisted of previously validated constructs on a 7 point Likert scale, measuring Science Identity (Chemers et al., 2011), Engagement in Biology (Wang et al., 2016), and Scientific Community Values (Estrada et al., 2011; Table 3). Additionally, we included short-answer responses to evaluate 1) course effectiveness, 2) student affect for each module and replacement texts, and 3) student learning gains (Supplementary Material).

We obtained IRB approval (20-376 EX 2008) from the appropriate institutional review boards, and we procured informed consent from participants before voluntary and anonymous participation in the study.

\section{Data Coding and Analysis}

We downloaded survey responses 1 week after the end of the semester. The response rate on the pre-course survey was an average of $75 \%$ between the two sections (traditional curriculum $=65 \%$; IA curriculum $=87 \%$ ) and the response rate for the post-course survey was $80 \%$ (traditional curriculum $=68 \%$; IA curriculum $=93 \%$ ). We parsed out survey responses into two data sets: 1) Likert-scale responses and 2) open responses.

\section{Likert-Scale Responses}

Because we used previously validated constructs (Science Identity, Engagement in Biology, and Science Community Values), and our sample sizes were insufficient for use in confirmatory factor analysis, we averaged individual responses for each construct on a per-student basis. We analyzed the data using linear
TABLE 2. Demographic breakdown of experimental sections

\begin{tabular}{lcc}
\hline Demographics & $\begin{array}{c}\text { IA modules } \\
(\mathbf{N}=\mathbf{5 1})\end{array}$ & $\begin{array}{c}\text { Traditional } \\
(\mathbf{N}=\mathbf{3 8})\end{array}$ \\
\hline Average age & 21.38 years & 22.23 years \\
Ethnicity & & \\
Asian/Pacific Islander & $1.9 \%$ & $7.9 \%$ \\
Black/African American & $39.2 \%$ & $42.1 \%$ \\
Hispanic or Latino & $9.8 \%$ & $\mathrm{NA}$ \\
Native American or American Indian & $1.9 \%$ & $\mathrm{NA}$ \\
White & $43.1 \%$ & $47.4 \%$ \\
Other & $3.9 \%$ & $2.6 \%$ \\
Class standing & & \\
Freshman & $33.3 \%$ & $5.2 \%$ \\
Sophomore & $43.1 \%$ & $50 \%$ \\
Junior & $21.6 \%$ & $39.5 \%$ \\
Senior & $1.9 \%$ & $5.3 \%$ \\
Major & & \\
Biology & & \\
Non-biology science field & $5.9 \%$ & $2.6 \%$ \\
Non-science & $13.8 \%$ & $21 \%$ \\
Undecided & $70.6 \%$ & $76.3 \%$ \\
Gender & $9.8 \%$ & $\mathrm{NA}$ \\
Woman & & \\
Woman/gender neutral & & \\
Man & & \\
Man/gender neutral & & \\
Prefer not to disclose & & \\
First-generation status & $32.7 \%$ & $\mathrm{NA}$ \\
No & $3.9 \%$ & $\mathrm{NA}$ \\
Yes & $27.5 \%$ & $42.1 \%$ \\
Unsure & $3.9 \%$ & $57.9 \%$ \\
\hline & $1.9 \%$ & $31.6 \%$ \\
& & $10.1 \%$ \\
\hline
\end{tabular}

mixed models (Pinheiro et al. , 2020), testing for reported gains in each of the three constructs between the two implementation types, including pre-course survey response as a random effect to control for incoming variation in student responses. We used anonymous identifiers in the model to account for repeated sampling.

\section{Open Responses}

We asked four open-response questions on the post-course survey (Table 4). For each of the open-response questions, two to three authors (depending on the question being assessed) created categories through first- and second-cycle analyses using open and thematic coding (Saldaña, 2013). Each question produced a number of coding themes (Table 4). Two to three independent researchers coded a subset of responses, at which point we adapted the coding themes to be increasingly inclusive and descriptive. We then coded responses into appropriate categories, where responses could be coded in more than one theme when necessary. We calculated percent agreement and percent exclusion on a per-question basis (Table 4). Of note, we excluded from the data set responses that were too vague for coding. After calculating percent agreement and exclusion, the same two or three researchers worked in collaboration to code all student responses to consensus. For cases in which two coders could 
TABLE 3. Likert-scale survey constructs

\begin{tabular}{|c|c|}
\hline Construct & Individual survey questions \\
\hline $\begin{array}{l}\text { Science Identity } \\
\quad \text { (Chemers et al., 2011) }\end{array}$ & $\begin{array}{l}\text { I have a strong sense of belonging to the scientific community of scientists. } \\
\text { I derive great personal satisfaction from working on a team that is doing important work. } \\
\text { I have come to think of myself as a scientist. } \\
\text { I feel like I belong in the field of science. } \\
\text { The daily work of a scientist is greatly appealing to me. }\end{array}$ \\
\hline $\begin{array}{l}\text { Engagement in Biology } \\
\text { (Wang et al., 2016) }\end{array}$ & $\begin{array}{l}\text { How hard were you working in class? } \\
\text { How well were you concentrating? } \\
\text { How important was what you were doing in class to you? } \\
\text { How important was this lesson to your future? } \\
\text { How interesting were the activities? } \\
\text { To what degree did you enjoy what you were doing? }\end{array}$ \\
\hline $\begin{array}{l}\text { Science Community Values } \\
\text { (Estrada et al., 2011) }\end{array}$ & $\begin{array}{l}\text { The material covered in class aligns with your views on the following concept: It is valuable to conduct research } \\
\text { that builds the world's scientific knowledge. } \\
\text { The material covered in class aligns with your views of the following concept: Discovering something new in the } \\
\text { sciences is thrilling. } \\
\text { The material covered in class aligns with your views of the following concept: Discussing new theories and ideas } \\
\text { between scientists is important. } \\
\text { Scientific research can solve many of today's world challenges. }\end{array}$ \\
\hline
\end{tabular}

not reach consensus, we consulted with an additional author until consensus could be reached.

\section{RESULTS}

\section{Student Perceptions of Science and Society}

In the first week of the semester of Introductory Biology, we asked students: "How does science impact social perspectives and problems?" Across treatments, students' open-ended responses indicated that science helps us to understand the world (25\%), answer societal problems (20.1\%), and combat misinformation (22.6\%; Figure 1). Despite this recognition, when students were asked whether or not they were aware of the topics presented in the IA modules before the class (on a seven-point Likert scale), $43 \%$ of students indicated they were not aware of topics related to unethical experimentation on people in biology research, $48 \%$ of students reported being unaware of the issues surrounding representation in STEM and science research, and $50 \%$ of students had not considered how biological science shapes societal views on identities (Figure 2A).

\section{Science Identity, Engagement, and Community Values}

In response to a series of Likert-scale survey items, we found no significant gains in the IA curriculum in comparison to the traditional curriculum in terms of science identity (estimate = $0.12, \mathrm{SE}=0.35, p=0.07$ ), engagement in biology (estimate $=$ $0.26, \mathrm{SE}=0.26, p=0.32$ ), or community values (estimate $=$ $0.03, \mathrm{SE}=0.25, p=0.89$ ).

\section{Student Perception of IA Materials}

Following the IA curricular interventions, students indicated $>68 \%$ approval and appreciation (agree to strongly agree) for the material in each of the modules (68\% "The Ugly Truth" module; 68\% "Representation in STEM" module; 69\% "Science and Identity" module; Figure 2A). Students reported that they perceived the alternative text we read in class, The Immortal Life of Henrietta Lacks, to be more useful than corresponding textbook chapters (79\% agree-strongly agree), more engaging than a textbook
(91\% agree-strongly agree), and more relevant to teaching about societal issues (93\% agree-strongly agree; Figure 2B).

We asked students what they liked and disliked about the curriculum using open-ended responses. Common themes emerged between the three modules (Figure 3). Students reported they learned something new in "The Ugly Truth", "Representation in STEM", and "Science and Identity" modules (i.e., $26 \%, 21 \%$, and $26 \%$ of students, respectively) and that the materials were interesting and informative $(23 \%, 14 \%$, and $18 \%$ of students, respectively). As was to be expected, module-specific patterns also arose. For instance, students were likely to mention ethics or scientific practices (26\% of students) in "The Ugly Truth" module, whereas they were likely to mention visible identities (18\% of students) in the "Representation in STEM" module, but hidden (17\% of students) and visible identities (17\% of students) in the "Science and Identity" module. Unsurprisingly, students were likely to view the more modern modules as relevant (3\% "Science and Identity" and $7 \%$ "Representation in STEM"). We found $18 \%$ of students made direct mention of the relatability of the materials in the "Representation in STEM" module, only 3\% of students did so in the "Science and Identity" module, and no students reported relatability in "The Ugly Truth" module (Figure 3).

Interestingly, the majority of students reported that they did not dislike any portion of the modules (30\% "The Ugly Truth", 59\% "Representation in STEM", 50\% "Science and Identity"). However, of the students who reported negative aspects of the modules, the most prominent was the bleakness of the material (28\% "The Ugly Truth", 19\% "Representation in STEM", 20\% "Science and Identity"; Figure 3). For example, one student reported "Though I liked many things about this module, it was hard to learn about certain experiments. Some that stick out to me were the Nazi Twin experiments as well as the Iowa Stuttering Study," while another reported they did not like "The ugly truth that science, like any discipline, is one of biases against certain groups. It's not a nice thing to see in a pursuit of pureness of intent." 
TABLE 4. Qualitative survey questions, coding categories, categorical descriptions, and methodological details

\begin{tabular}{|c|c|c|c|c|c|}
\hline Question & Coding categories & Description & Coders & $\%$ Agree & \% Exclude \\
\hline \multirow{7}{*}{$\begin{array}{l}\text { How does science } \\
\text { impact social } \\
\text { perspectives } \\
\text { and problems? }\end{array}$} & $\begin{array}{l}\text { Influences Understand- } \\
\text { ing of the World }\end{array}$ & $\begin{array}{l}\text { Mentions how things work, observations, how they work, } \\
\text { or how people observe the natural world }\end{array}$ & $\begin{array}{l}\text { C.J.B., S.E., } \\
\text { T.G. }\end{array}$ & $100 \%$ & $8 \%$ \\
\hline & Influences Morality & $\begin{array}{l}\text { Mentions morality and ethical concerns Influences ethical } \\
\text { perspectives }\end{array}$ & & & \\
\hline & Negatively & $\begin{array}{l}\text { Mentions science can have negative effects on society, } \\
\text { negative agendas, etc. }\end{array}$ & & & \\
\hline & $\begin{array}{l}\text { Provide Answers to } \\
\text { Societal Problems }\end{array}$ & $\begin{array}{l}\text { Discusses how science provides answers to societal issues, } \\
\text { social or practical, makes life easier, ir improves } \\
\text { quality of life }\end{array}$ & & & \\
\hline & $\begin{array}{l}\text { Combat Misinforma- } \\
\text { tion }\end{array}$ & $\begin{array}{l}\text { Emphasizes uncovering truths rather than falsehoods or } \\
\text { prevent the consumption of misinformation }\end{array}$ & & & \\
\hline & $\begin{array}{l}\text { Provide More } \\
\quad \text { Perspectives }\end{array}$ & $\begin{array}{l}\text { Provides multiple solutions or perspectives on issues from } \\
\text { different geographic areas or sections of society }\end{array}$ & & & \\
\hline & Concrete & Uses scientific terms such as "data," "findings," "studies" & & & \\
\hline \multirow{6}{*}{$\begin{array}{l}\text { What did you like } \\
\text { about this } \\
\text { module? }\end{array}$} & $\begin{array}{l}\text { Learned Something } \\
\text { New/Informative }\end{array}$ & $\begin{array}{l}\text { Mentions the gain of new knowledge or the informative } \\
\text { nature of the materials. }\end{array}$ & & & \\
\hline & Interesting/Engaging & Indicates that material was interesting or engaging & & & \\
\hline & Relevant & $\begin{array}{l}\text { Indicates that the materials are relevant or timely to } \\
\text { current societal issues }\end{array}$ & & & \\
\hline & Honesty & Indicates full disclosure and honesty of materials & & & \\
\hline & $\begin{array}{l}\text { Relatable/Helpful to } \\
\text { Themselves or } \\
\text { Others }\end{array}$ & $\begin{array}{l}\text { Mentions they personally relate to the material or } \\
\text { recognize how it may be personally helpful to them or } \\
\text { others. }\end{array}$ & & & \\
\hline & $\begin{array}{l}\text { Mention of Visible } \\
\text { Identities }\end{array}$ & Mentions the inclusion of visible identities. & & & \\
\hline \multirow{5}{*}{$\begin{array}{l}\text { What did you } \\
\text { dislike about } \\
\text { this module? }\end{array}$} & Content Bleakness & $\begin{array}{l}\text { Mentions the content itself was bleak, or sad, and it led to } \\
\text { their dislike of the material }\end{array}$ & & & \\
\hline & Mundane & Indicates that the material was not engaging & & & \\
\hline & Material Complexity & $\begin{array}{l}\text { States the complexity of the material and/or depth of the } \\
\text { material was too difficult }\end{array}$ & & & \\
\hline & $\begin{array}{l}\text { Not Enough } \\
\text { Information }\end{array}$ & $\begin{array}{l}\text { Reports of modules being too vague or not containing } \\
\text { enough information }\end{array}$ & & & \\
\hline & $\begin{array}{l}\text { Overabundance of } \\
\text { Material }\end{array}$ & States the lessons took too long to cover or was too dense. & & & \\
\hline
\end{tabular}

There has always been a concern that addressing these societal issues could have disproportional negative effects on persons excluded because of their ethnicity or race (PEERs; Asai, 2020). However, our findings indicate that, in all three modules, students who self-identified as belonging to a PEER group were more likely to approve of the inclusion of the IA materials following their implementation than students from non-PEER groups (Figure 4). While $76 \%$ and $71 \%$ of students from PEER groups reported enjoyment and approval (agreestrongly agree) of the included materials in the "Representation in STEM" and "Science and Identity" modules respectively, only $65 \%$ of students in non-PEER groups felt the same about both of those modules. When surveyed on their view of "The Ugly Truth" module, 79\% of students from PEER backgrounds responded positively (agree-strongly agree), while 56\% of students in non-PEER groups reported enjoyment of and approval for the materials. Interestingly, a large proportion of students from non-PEER groups (i.e., 44\%) reported neutrality to "The Ugly Truth" module, while none of the students reported negative feelings toward their inclusion (Figure 4). 


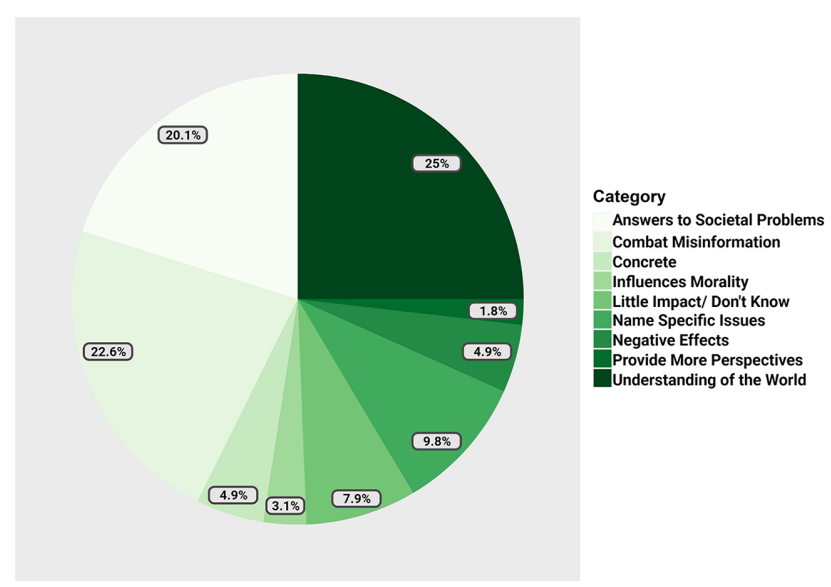

FIGURE 1. Student perceptions of science's impact on social perspectives and problems. Student responses were binned into nine categories, and the pie chart shows the proportion of responses within each category. Students were most likely to associate science with increasing our understanding of the world (25\%), providing answers to societal problems $(20.1 \%)$, and combating misinformation (22.6\%).

\section{Student Knowledge of Societally Impactful Topics}

When prompted to agree or disagree on a 7-point Likert scale ranging from strongly agree to strongly disagree with the prompt "I am knowledgeable about the impact of biology on societal issues" on the pre-course survey, $20 \%$ of students in the traditional curriculum disagreed to some extent (disagree-strongly disagree) with the statement. In the IA curricular group, 20\% of students also reported that they disagreed to some extent (disagree-strongly disagree). However, we observed an interesting trade-off in neutrality. While $50 \%$ of students in the traditional curriculum reported neutrality to the question, only $9 \%$ of students in the IA curriculum reported neutrality, leading to $72 \%$ of students reporting agreement with the statement (agreestrongly agree). This is noticeably more students reporting confidence in their knowledge of the relationship between biology and society following IA curriculum than in the traditional curriculum ( $72 \%$ and $30 \%$ agree-strongly agree, respectively). Additionally, no students in the IA curriculum responded with strongly disagree or disagree to the prompt; the lowest student report was "somewhat disagree" (Figure 5). We caution readers in their interpretations of these results, however, by emphasizing these are student perceptions of knowledge rather than meaningful reflections of actual knowledge gains.
A

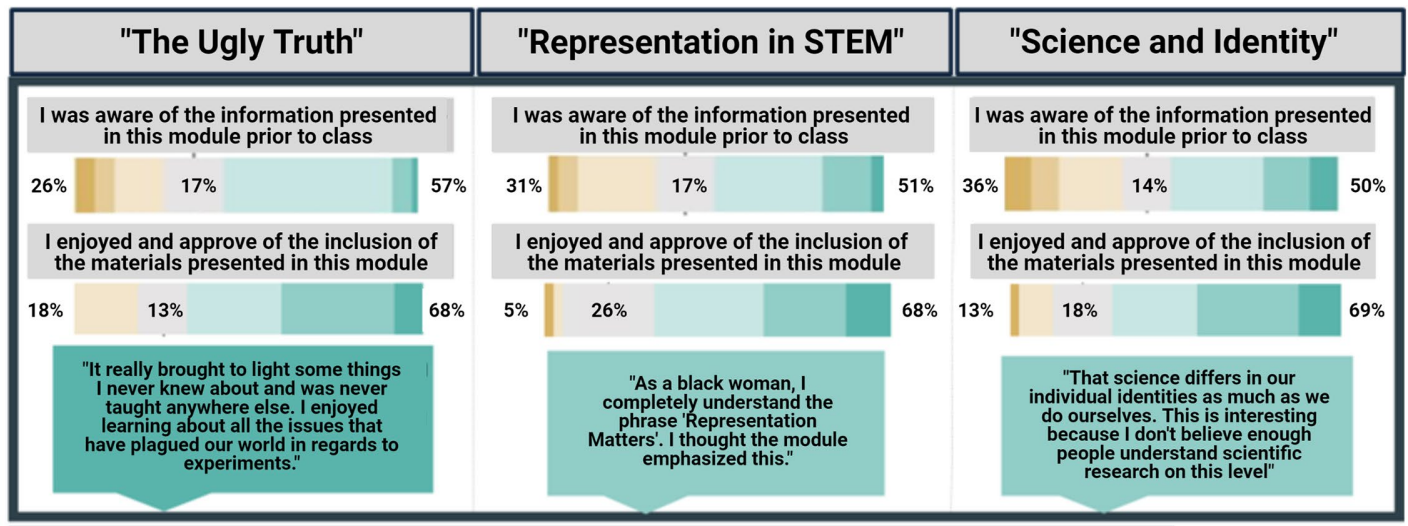

B

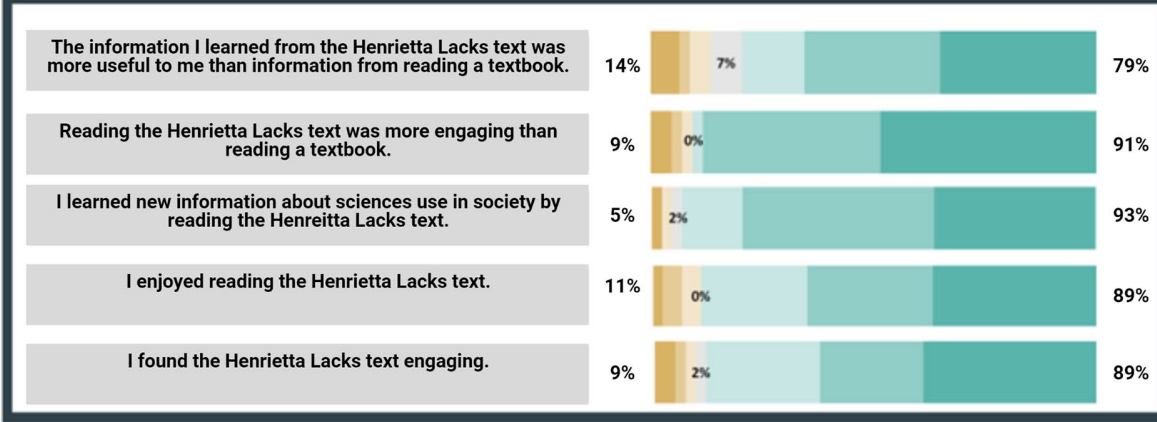

Strongly Disagree Disagree Somewhat Disagree Neutral Somewhat Agree Agree Strongly Agree

FIGURE 2. Student perception of IA materials in the introductory classroom. Likert-scale responses (7-point scale ranging from strongly agree to strongly disagree) are presented as bar graphs depicting the proportion of students who respond positively (percentage on right), negatively (percentage on left), and neutrally (percentage in gray). (A) For each of the three modules, students were asked to respond to their awareness of the materials (top) and their approval and enjoyment of the materials (middle). Within each module, between $43 \%$ and $50 \%$ of students were unaware of the materials before entering the classroom, and greater than $68 \%$ of students expressed appreciation for the inclusion of IA materials. For each module, one student qualitative response is provided highlighting common benefits of the materials. Student quotes are color coded to their respective Likert-scale responses. (B) When traditional textbook readings were replaced with The Immortal Life of Henrietta Lacks, students reported high levels of engagement, societal connections, and utility. 


\section{A What did you like about this module?}

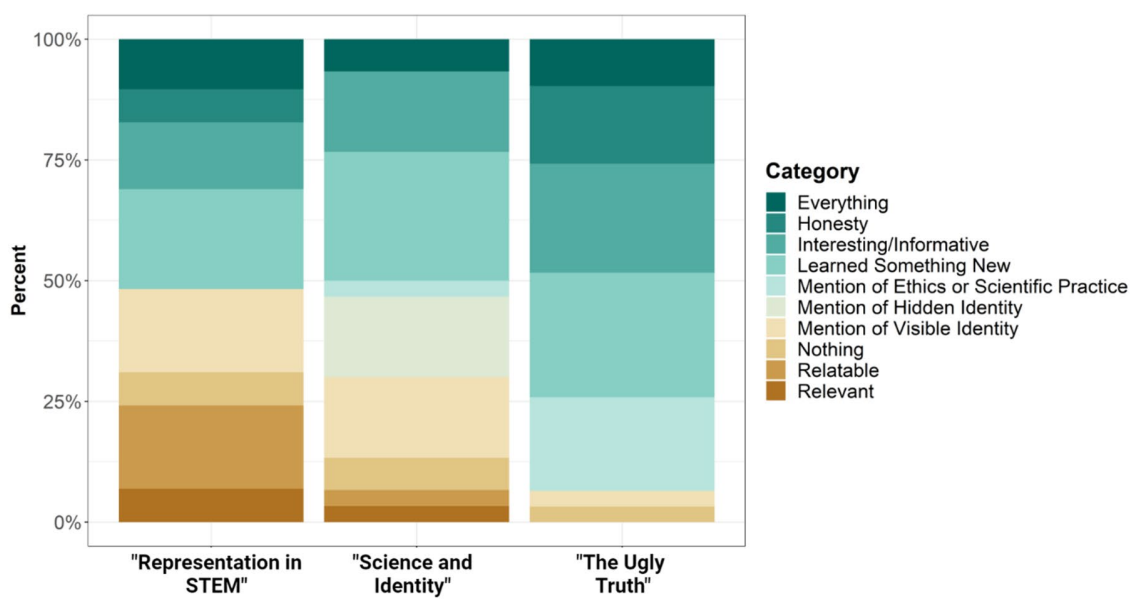

I What did you dislike about this module?

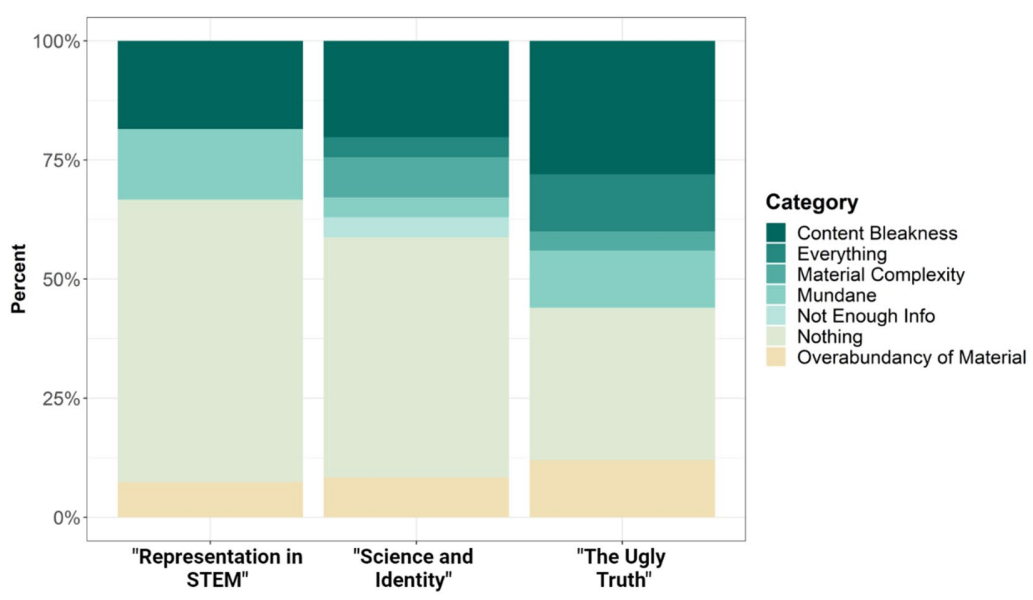

FIGURE 3. Coded responses to the prompts (A) What did you like about this module? Students reported common likes across modules, including reports of learning something new and the interesting and informative nature of the materials. Student responses matched well to materials presented (e.g., ethics in "The Ugly Truth" and visible identities in the "Representation in STEM" module). (B) What did you dislike about this module? The majority of students reported that they did not dislike any portion of the modules (i.e., "nothing"). However, of the students who reported specific dislikes, the most prominent in all three modules was the bleakness of the materials.

Participation in IA modules also positively impacted student perceptions of diverse scientific identities. For instance, when given an opportunity to name as many scientists as possible over 2 minutes, students exposed to IA modules named more women scientists and scientists of color compared with students in the control section. Students in the traditional curriculum were $2.9 \%$ more likely to identify a scientist of color following the course, while students exposed to the IA curriculum displayed an 3-fold increase, or an increase of approximately $20.4 \%$ (Figure 6).

\section{DISCUSSION}

We tested the impacts of integrating an IA curriculum into a biology course for non-majors by including three modules at the end of the semester that focused on 1) unethical experimentation and human rights evolution, 2) representation in STEM, and 3) the intersection of science and identity. Our research questions centered on students' understandings of the relationship between science and society, their perceptions of the IA materials, and whether their knowledge of societally impactful topics changed after exposure to the curriculum. Previous work shows instructors believe science was not the appropriate subject to broach such topics (Sadler et al., 2006), but our data suggest students responded positively to these modules, and the inclusion of IA materials impacted how students think about science and scientists.

\section{Student Perception of Science and Society}

Across the two treatments, students most frequently reported that science impacts social perspectives and problems by improving our understanding of how the world works, by providing solutions to societal problems, and by combating misinformation. We found these reflections aligned well with the conversations generated by the IA materials, which often sat at the intersection of biology and society. These responses suggest to us that students desire discussions about topics that strike at the core of the IA curriculum.

\section{Impact of IA Inclusion on Science Identity and Science Community}

The IA section and the traditional section of Introductory Biology did not differ with respect to their gains in measures of science identity, engagement in biology, and science community values over the semester. While we were surprised by these null results, they may hint at the possibility that IA materials do not impact these particular affective traits. Additionally, it is possible that the timing of IA integration, length of time dedicated to IA topics, and the nature of integration with nonmajors curriculum may impact these constructs.

Past research has demonstrated that teaching within the context of socioscientific issues, or those that directly apply biological or scientific principles to societal problems, can increase students' moral sensitivity and potentially their overall moral development (Fowler et al., 2009). Lee et al. (2013) found that the implementation of 3-4weeks of socioscientific issues material in a ninth-grade genetic curriculum promoted students' character and values as global citizens. As a result, students were more concerned for and more sensitive to the plight of those who are jeopardized because of technological advancements. Conversely, our focus related less to student capacity for 


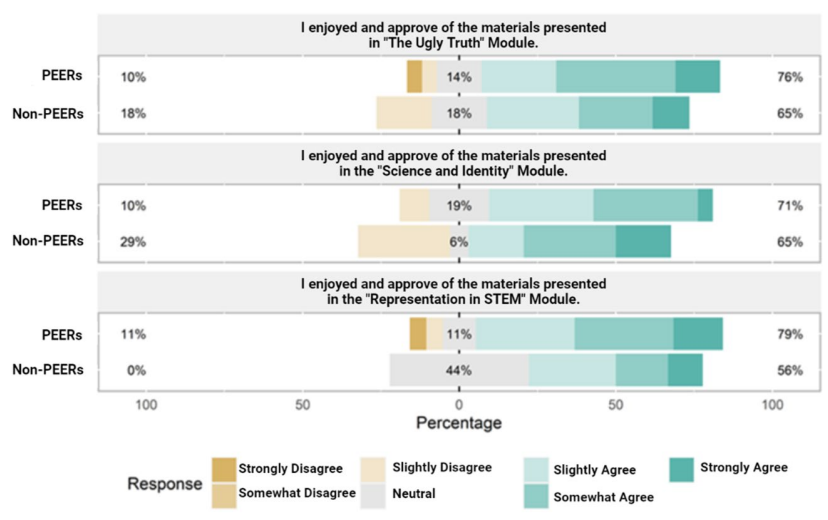

FIGURE 4. Student approval of material by representation status. Students who self-reported as PEERs reported higher levels of approval for each of the three IA modules than students who identify as non-PEERs.

empathy and more to students identifying as scientists and agreeing with science community values.

Another possible explanation underlying these results may relate to students perceiving these topics as detached from their lived experiences, particularly those that occurred before they were born (Zeidler et al., 2019), or experiences that they find personally relatable through empathetic or sympathetic responses. For example, much of "The Ugly Truth" model was centered on examples occurring before the 21st century. Additionally, students who personally related to the "Science and Identity" module were likely to be in the minority based on national demographics (i.e. students who identify as part of a minoritized demographic, such as the LGBTQIA+ community). As a result, students may have found the materials in "The Ugly Truth" module to be less relatable than that of the other modules, and therefore were less likely to impact their feelings of belonging within the field. This is supported by the absence of "relatability" reported by students in their short-answer responses to each of the aforementioned modules, while relatability was frequently mentioned in reference to the "Representation in STEM" module (Figure 3A).

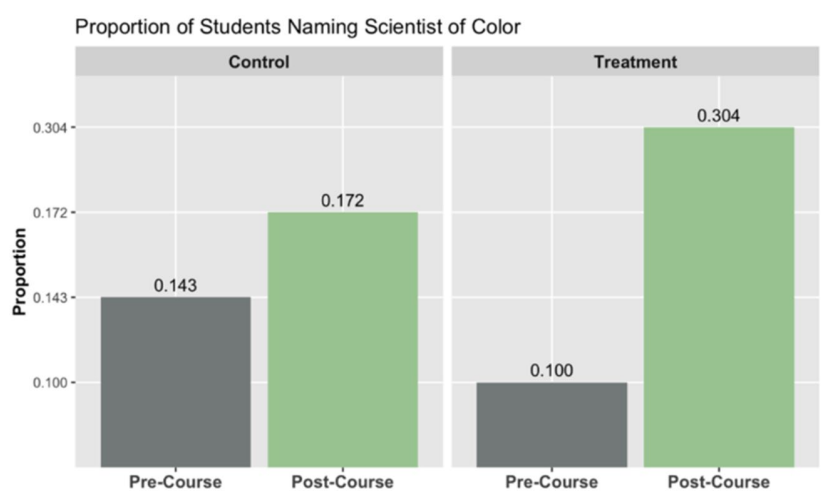

FIGURE 6. Student recall of scientists from diverse backgrounds. When prompted to list scientists by name, students exposed to IA modules listed $\mathbf{2 0 . 4 \%}$ more scientists from diverse backgrounds, while students in the control section listed $2.9 \%$ more (gains between pre- and post-course survey reports).

\section{Student Perception of IA Materials}

Following the interventions, students overwhelmingly indicated approval of the materials in each module, and a vast majority perceived The Immortal Life of Henrietta Lacks to be more useful, engaging, and relevant than a traditional biology textbook (Figure 2B). It is important to note that students were not required to read the traditional textbook in the IA section at any point during the semester, although it was available to them as an optional text, and students' responses may be influenced by previous experiences with textbooks rather than a sole comparison with the textbook traditionally used in the course. We were particularly interested in the impacts these materials had on students who possess racial identities that have been historically marginalized in science (e.g., those who could personally identify with aspects of focal individuals described in the IA curriculum). Such students are at a greater risk of being tokenized (Muhs et al., 2012) and receiving microaggressions in the classroom (Harrison and Tanner, 2018). We considered the possibility that these offenses would increase during class discussions.

However, our results showed that students who identify as a PEER reported equal or higher approval of IA materials than non-PEER students. Thus, while students may be affected differently by exposure to such materials, on average, we found that PEERs approved of their integration as much as, if not more, than their non-PEER peers in the classroom. Though these results are encouraging, we caution readers in their interpretation of these results, because we tested these materials in a single section at a single institution, and the courses were racially diverse. Thus, students who are racially underrepresented in STEM were well represented in these classes, reducing the possibility that such students are the only individuals in group discussions on these topics. Future work will benefit from investigations incorporating these curricula into other institutional contexts, class sizes, and course
FIGURE 5. Self-reported knowledge of societally impactful topics. Before IA materials students reported $50 \%$ neutrality and $30 \%$ positive feelings toward their knowledge about the impact of biology on societal issues. Following exposure to IA materials, neutrality decreased to $9 \%$, while positive reports increased to $72 \%$, indicating that students felt more knowledgeable on the intersection of biology and society following participation in the IA curriculum. 
levels (i.e., lower vs. upper division). Additionally, qualitative approaches to addressing the impact of these materials on students with marginalized identities would allow more in-depth and nuanced understanding. Finally, when any classroom topic relates to people's identities, inclusive approaches and language choices are critical (Hales, 2020). We acknowledge that one reason for the success of these modules may have been, in part, due to the impact of an instructor well versed in inclusive pedagogy.

\section{Student Knowledge of Societally Impactful Topics}

Across both class sections, $43 \%$ of students were not aware of topics related to unethical experimentation on people in biology research and $48 \%$ of students had not considered how biological science shapes societal views on identities. This shows a persistent deficiency in how students' prior education highlights IA in science.

After participation in IA modules, we found students were three times more likely to name women scientists and scientists of color during an exercise in which we asked students to name as many scientists as possible over 2 minutes. Thus, implementing IA materials may prove one effective strategy in combating the stereotype that only people with certain overrepresented and privileged backgrounds and identities can be scientists. These results also align with previous work showing recognition of scientists from diverse backgrounds can have positive impacts on student outcomes (e.g., increased empathy, student performance, interest in science; Schinske et al., 2016). While we cannot pinpoint the IA modules as the underlying reason why so many more students named nontraditional scientists, we point to the possibility that students exposed to IA modules were more likely to confront their own unintentional biases when asked that survey question.

\section{Moving Forward}

Previous work has explored learning goals for nonscientists and suggested they may be distinct from those of developing scientists (Miller, 2004; Klymkowsky, 2005; Feinstein et al., 2013; Ballen et al., 2017). For example, scientific literacy skills, or the ability to access and make sense of science relevant to their daily lives (Feinstein et al., 2013), may be more critical to promote among students for whom an introductory biology course is their only exposure to science throughout higher education. Similarly, the ability to apply evidence-based solutions to personally meaningful problems will be particularly important as nonmajors regularly engage with scientific issues relevant to their daily lives after they leave the biology classroom. However, we also argue that teaching IA is important for students majoring in biology and other science disciplines. Such students may be less likely to take classes that consider the social elements or real-world implications of biology and science.

Thus, integration of IA materials in lower-level biology may be students' only opportunity to discuss the prevalence of biases, stereotypes, and assumptions that shape science. Whether we are preparing nonscientists to evaluate science in the media or preparing biologists for a career that impacts society through scientific advancement, it is important for students to leave the classroom with a deeper understanding of how science impacts the world around them, as well as their role in this interaction.

\section{Accessing Materials}

All survey instruments used to complete this study are available in the Supplemental Materials.

\section{ACKNOWLEDGMENTS}

We would like to thank the Auburn University Montgomery Biology Department for their encouragement and support along with each AUM student who graciously chose to participate in this study. We would also like to thank the Auburn Biology Department DEI Board as well as the Ballen and Schwartz laboratories for their valuable input during the development of this article. This work is supported by NSF-DUE-2120934 awarded to A.E.B. and C.J.B.

\section{REFERENCES}

Aikenhead, G. (2002). Renegotiating the culture of school science: Scientific literacy for an informed public. http://www.usask.ca/education/people/ aikenhead/portugal.htm

Aikenhead, G. S. (1985). Collective decision making in the social context of science. Science Education, 69(4), 453-475.

American Association for the Advancement of Science. (2011). Vision and change in undergraduate biology education: A call to action. Retrieved October 13, 2020, from https://visionandchange.org

Asai, D. J. (2020). Race matters. Cell, 181(4), 754-757. doi: 10.1016/j cell.2020.03.044

Ballen, C. J., Blum, J. E., Brownell, S., Hebert, S., Hewlett, J., Klein, J. R., ... \& Cotner, S. (2017). A call to develop course-based undergraduate research experiences (CUREs) for nonmajors courses. CBE-Life Sciences Education, 16(2), 1-7. doi: 10.1187/cbe.16-12-0352

Chambers, D. W. (1983). Stereotypic images of the scientist: The Draw-a-Scientist test. Science Education, 67(2), 255-265. doi: 10.1002/ sce.3730670213

Chemers, M. M., Zurbriggen, E. L., Syed, M., Goza, B. K., \& Bearman, S. (2011). The role of efficacy and identity in science career commitment among underrepresented minority students. Journal of Social Issues, 67(3), 469-491. doi: 10.1111/j.1540-4560.2011.01710.x

Cross, R. T., \& Price, R. F. (1996). Science teachers' social conscience and the role of controversial issues in the teaching of science. Journal of Research in Science Teaching, 33(3), 319-333. doi: https://doi.org/10.1002/ (SICI)1098-2736(199603)33:3<319::AID-TEA5>3.0.CO;2-W

Dawson, V. M., \& Venville, G. (2010). Teaching strategies for developing students' argumentation skills about socioscientific issues in high school genetics. Research in Science Education, 40(2), 133-148. doi: 10.1007/ s11165-008-9104-y

Douglas, H. (2009). Science, policy, and the value-free ideal (1st ed.) Pittsburgh, PA: University of Pittsburgh Press.

Driver, R., Newton, P., \& Osborne, J. (2000). Establishing the norms of scientific argumentation in classrooms. Science Education, 84(3), 287-312. doi: https://doi.org/10.1002/(SICI)1098-237X(200005)84:3<287::AID -SCE1>3.0.CO;2-A

Dzirasa, K. (2020). For Black scientists, the sorrow is also personal. Cell, 182(2), 263-264. doi: 10.1016/j.cell.2020.06.028

Eastwood, J. L., Sadler, T. D., Zeidler, D. L., Lewis, A., Amiri, L., \& Applebaum, S. (2012). Contextualizing nature of science instruction in socioscientific issues. International Journal of Science Education, 34(15), 2289-2315. doi: 10.1080/09500693.2012.667582

Elliott, K. C. (2017). A tapestry of values: An introduction to values in science (1st ed.). New York: Oxford University Press

Estrada, M., Woodcock, A., Hernandez, P. R., \& Schultz, P. W. (2011). Toward a model of social influence that explains minority student integration into the scientific community. Journal of Educational Psychology, 103(1), 206-222. doi: 10.1037/a0020743

Feinstein, N., Allen, S., \& Jenkins, E. (2013). Outside the pipeline: Reimagining science education for nonscientists. Science, 340(6130), 314-317. doi: 10.1126/science.1230855

Fowler, S. R., Zeidler, D. L., \& Sadler, T. D. (2009). Moral sensitivity in the context of socioscientific issues in high school science students 
International Journal of Science Education, 31(2), 279-296. doi: 10.1080/09500690701787909

Freire, P., \& Macedo, D. (2018). Pedagogy of the oppressed: 50th anniversary edition (4th ed.). New York: Bloomsbury Academic

Gewin, V. (2020). What Black scientists want from colleagues and their institutions. Nature, 583(7815), 319-322. doi: 10.1038/d41586-020 $-01883-8$

Hales, K. G. (2020). Signaling inclusivity in undergraduate biology courses through deliberate framing of genetics topics relevant to gender identity, disability, and race. CBE-Life Sciences Education, 19(2), es2. doi: 10.1187/cbe.19-08-0156

Harrison, C., \& Tanner, K. D. (2018). Language matters: Considering microaggressions in science. CBE-Life Sciences Education, 17(1), fe4. doi 10.1187/cbe.18-01-0011

Klymkowsky, M. W. (2005). Points of view: Content versus process: Is this a fair choice? Cell Biology Education, 4(3), 196-198. doi: 10.1187/cbe.05 $-04-0073$

Lazarowitz, R., \& Bloch, I. (2005). Awareness of societal issues among high school biology teachers teaching genetics. Journal of Science Education and Technology, 14(5), 437-457. doi: 10.1007/s10956-005-0220-4

Lee, H., Yoo, J., Choi, K, Kim, S.-W., Krajcik, J., Herman, B. C., \& Zeidler, D. L. (2013). Socioscientific issues as a vehicle for promoting character and values for global citizens. International Journal of Science Education, 35(12), 2079-2113. doi: 10.1080/09500693.2012.749546

Miller, J. (2004). Public understanding of, and attitudes toward, scientific research: What we know and what we need to know. Public Understanding of Science, 13. doi: 10.1177/0963662504044908

Muhs, G. G. Y., Niemann, Y. F., González, C. G., \& Harris, A. P. (2012). Presumed incompetent: The intersections of race and class for women in academia (1st ed.). Boulder, CO: University Press of Colorado \& Utah State University Press.

Perez, C. C. (2019). Invisible women: Data bias in a world designed for men (1st ed.). New York: Harry N. Abrams.

Phillips, J., \& Hausbeck, K. (2000). Just beneath the surface: Rereading geology, rescripting the knowledge-power nexus. Women's Studies Quarterly, 28(1/2), 181-202. JSTOR. Retrieved from JSTOR.

Pinheiro, J., Bates, D., DebRoy, S., Sarkar, D., \& R. Core Team. (2020). nlme: Linear and nonlinear mixed effects models (R package version 3.1-148). Retrieved September 20, 2015, from https://CRAN.R-project.org/ package $=n l m e$

Potochnik, A. (2020). Awareness of our biases is essential to good science. Retrieved August 8, 2021, from www.scientificamerican.com/article/ awareness-of-our-biases-is-essential-to-good-science/

Sadler, T. D., Amirshokoohi, A., Kazempour, M., \& Allspaw, K. M. (2006) Socioscience and ethics in science classrooms: Teacher perspectives and strategies. Journal of Research in Science Teaching, 43(4), 353-376. doi: https://doi.org/10.1002/tea.20142
Sadler, T. D., \& Zeidler, D. L. (2004). The morality of socioscientific issues: Construal and resolution of genetic engineering dilemmas. Science Education, 88(1), 4-27. doi: https://doi.org/10.1002/sce.10101

Saldaña, J. (2013). The coding manual for qualitative researchers (2nd ed). Los Angeles: Sage.

Schell, C. J., Guy, C., Shelton, D. S., Campbell-Staton, S. C., Sealey, B. A., Lee, D. N., \& Harris, N. C. (2020). Recreating Wakanda by promoting Black excellence in ecology and evolution. Nature Ecology \& Evolution, 4(10), 1285-1287. doi: 10.1038/s41559-020-1266-7

Schinske, J. N., Perkins, H., Snyder, A., \& Wyer, M. (2016). Scientist Spotlight homework assignments shift students' stereotypes of scientists and enhance science identity in a diverse introductory science class. CBE-Life Sciences Education, 15(3), ar47. doi: 10.1187/cbe.16-01-0002

Simpson, D. Y., Beatty, A. E., \& Ballen, C. J. (2021). Teaching between the lines: Representation in science textbooks. Trends in Ecology \& Evolution, 36(1), 4-8. doi: 10.1016/j.tree.2020.10.010

Solomon, J. (1992). The classroom discussion of science-based social issues presented on television: Knowledge, attitudes and values. International Journal of Science Education, 14(4), 431-444. doi: 10.1080/0950069920140406

Thomas, M. D., Henley, T. B., \& Snell, C. M. (2006). The Draw a Scientist test: A different population and a somewhat different story. College Student Journal, 40(1), 140-148.

Wang, M.-T., Fredricks, J. A., Ye, F., Hofkens, T. L., \& Linn, J. S. (2016). The Math and Science Engagement Scales: Scale development, validation, and psychometric properties. Learning and Instruction, 43, 16-26. doi: 10.1016/j.learninstruc.2016.01.008

Wood, S., Henning, J. A., Chen, L., McKibben, T., Smith, M. L., Weber, M., ... \& Ballen, C. J. (2020). A scientist like me: Demographic analysis of biology textbooks reveals both progress and long-term lags. Proceedings of the Royal Society B: Biological Sciences, 287(1929), 20200877. doi: 10.1098/ rspb.2020.0877

Zeidler, D. L. (1997). The central role of fallacious thinking in science education. Science Education, 81(4), 483-496. doi: https://doi.org/10.1002/ (SICI)1098-237X(199707)81:4<483::AID-SCE7>3.0.CO;2-8

Zeidler, D. L., Herman, B. C., \& Sadler, T. D. (2019). New directions in socioscientific issues research. Disciplinary and Interdisciplinary Science Education Research, 1(1), 11. doi: 10.1186/s43031-019-0008-7

Zeidler, D. L., Lederman, N. G., \& Taylor, S. C. (1992). Fallacies and student discourse: Conceptualizing the role of critical thinking in science education. Science Education, 76(4), 437-450. doi: https://doi.org/10.1002/ sce. 3730760407

Zeidler, D. L., Sadler, T. D., Simmons, M. L., \& Howes, E. V. (2005). Beyond STS A research-based framework for socioscientific issues education. Science Education, 89(3), 357-377. doi: https://doi.org/10.1002/sce.20048

Zohar, A., \& Nemet, F. (2002). Fostering students' knowledge and argumentation skills through dilemmas in human genetics. Journal of Research in Science Teaching, 39(1), 35-62. doi: https://doi.org/10.1002/tea.10008 